\title{
A Cohort Study on Some Immunohematological Parameters in Brucellosis Affected Cattle
}

\author{
Anju Mohan and Hari Mohan Saxena* \\ Department of Veterinary Microbiology, College of Veterinary Science, GADVASU, Ludhiana 141004 India.
}

\begin{abstract}
Little is known about host immunodynamics during Brucellosis. We conducted immunohematological study in Brucellosis affected cattle for 3 months. Serum proteins and globulins were decreased very significantly $(P<0.01)$ from zero day $(O D)$ to $90 D$ and significantly $(P<0.05)$ from $0 D$ to $30 D$. Globulins decreased significantly $(P<0.05)$ from OD to 75D. Titers of anti-Brucella antibodies by Standard Tube Agglutination Test, Microagglutination Test and Indirect Hemagglutination did not differ significantly among themselves from $O D$ to 90D. However, in ELISA, there was a very significant ( $p<0.01)$ increase in titers from ODay to 60D, $75 D$ and 90D; from 30Day to 60D, $75 \mathrm{D}$ and $90 \mathrm{D}$; and from 45Day to 60D, $75 \mathrm{D}$ and $90 \mathrm{D}$, respectively. Levels of leukocytes, lymphocytes and neutrophils did not differ significantly. However, monocyte levels increased from $45 D$ to $60 D$ and then decreased from $60 D$ to $75 D$ significantly $(P<0.05)$. Data reflects the immunohematological dynamics in response to disease and provides insight for suitable intervention.
\end{abstract}

Keywords: Cohort study, Brucellosis, cattle, anti-Brucella antibodies, cellular immunity.

\section{Introduction}

Brucellosis is an important zoonotic disease and has worldwide distribution among humans as well as animals (Jain et al., 2013; Pandeya et al., 2013). About 500,000 cases of human brucellosis are estimated to occur worldwide every year. It causes heavy economic loss to the animal industry through delayed conception, late-term abortions and retention of placenta and temporary or permanent infertility (Kollannur et al., 2007) in females and orchitis and epididymitis in males, with excretion of organisms in semen, uterine discharges, and in milk (Godfroid et al., 2013). The disease is usually asymptomatic in non-pregnant cows (Schuurman, 1983). Brucella is usually transmitted to humans through the consumption of raw milk and its products (milk cream, butter, and fresh cheese) or through contact with afterbirth products from infected animals (Godfroid et al., 2013; Moriyon et al, 2004). Once infected, the animal may continue to shed bacteria and remains a source of infection to others for long period (Pandeya et al., 2013).Bovine brucellosis is endemic in all states of India. The occurrence of Brucellosis in India is reportedly to the extent of $10 \%$ in the marginal herds and $50 \%$ in organized farms. In Punjab, overall $17.7 \%$ prevalence of brucellosis was reported in cattle and buffaloes. The economic impact of the disease was estimated to be Rs. 500 crores annually (Jain et al., 2013; Pandeya et al., 2013). The study of blood constituents can provide valuable information about the general health of the animal and, therefore, can be used for evaluating the health status of the animal. Brucellosis has serious effects on animal health because it infects vital organs in the body leading to their damage and impairment of their function. Very little information is available regarding any periodic variation in the status of blood immunohematological profile in relation to disease progression in cattle suffering from brucellosis. Although there is vast information on various aspects of bovine Brucellosis in the available literature, there is hardly any published report on the exact progressive status of various immunohematological parameters (like serum proteins, globulins, specific antibodies and immune cells) in cattle as the disease advances. This information is vital as it could shed some light on the pathogenesis of the disease, prognosis and the line of treatment to be undertaken in each case. Keeping this in mind, the present study was conducted with the objective to investigate the changes in some biochemical and immunohematological parameters of cattle affected with brucellosis. Here we present the results of a cohort study on some immunohematologic parameters in Brucellosis affected cattle observed at regular intervals over a period of 3 months.

\section{Ethical approval}

\section{Materials And Methods}

All the experimental protocols performed on cattle were approved by the Institutional Animal Ethics Committee (IAEC). Animals were kept in IAEC approved facilities as per the guidelines and received feed and water ad libitum.

Infected cattle

Adult Holstein Friesian cattle maintained at the University Dairy Farm, which had been vaccinated during calf hood with B. abortus strain 19 vaccine (Bruvax; Indian Immunologicals) and got naturally infected with Brucellosis were included in the study. 
A cohort study on some immunohematological parameters in Brucellosis affected cattle

\section{Collection of blood}

Blood samples were collected from Brucellosis affected cattle through jugular vein at $0,30,45,60,75$ and 90 days intervals. Anticoagulated blood was collected for estimating levels of leukocytes and their subsets while sera were separated from clotted blood and stored at $-20^{\circ} \mathrm{C}$ until further use for studying the immune response of the animals to the infection.

\section{Analysis of immune responses}

Estimation of total protein levels in serum samples

The total protein content in serum samples of cattle at $0,30,45,60,75$ and 90 days intervals were determined by using Vitros TP slides and the Vitros DTSC (Johnson \& Johnson Company) instrument.

\section{Estimation of total globulin levels in serum samples}

The total globulin levels in the serum samples of cattle at $0,30,45,60,75$ and 90 days intervals were estimated by substracting albumin content from the total protein level determined by using Vitros TP slides, Vitros ALB DT slides and the Vitros DTSC (Johnson \& Johnson Company) instrument.

\section{Estimation of antibody titers in sera:}

Antibody titers in the serum samples of cattle at 0,30, 45, 60, 75 and 90 days intervals were estimated by Standard Tube Agglutination Test (STAT), Microtiter plate Agglutination Test (MAT), Indirect Hemagglutination Assay (IHA) and Enzyme-Linked ImmunoSorbent Assay (ELISA). The methods followed have been described earlier (Mohan et al., 2016).

\section{Estimation of Total Leukocyte Counts (TLC) in the blood}

Approximately $20 \mu 1$ of blood from Brucellosis affected cattle was mixed with $300 \mu 1$ of WBC diluting fluid (BTL Research Lab, India) and kept for 10 min undisturbed. One drop of the diluted blood was loaded into Neaubeaur's counting slide and a cover slip was put over it. The number of cells in the WBC counting chamber was counted under a microscope.

\section{Estimation of Differential Leukocyte Counts (DLC) in the blood}

Blood smear from cattle was prepared on a clean microscopic slide and the slide was air dried. Fixation was done by immersing the slide in methanol for around 5 min. The slide was then flooded with Giemsa stain and kept for $10 \mathrm{~min}$. Afterwards it was washed in running water and kept for drying. The slide was observed under a microscope and the cells were counted up to a total of 100 cells.

\section{Statistical analysis of data:}

Data were statistically analyzed by subjecting to analysis of variance.

\section{Results And Discussion}

Evaluation of protein and gamma globulin fractions in combination with other clinical and immunohematological data is helpful in charting the disease process, diagnosis and prognosis and may help in understanding the pathophysiology of Brucella infection in cattle.

Serum protein levels $(\mathrm{g} / \mathrm{dl})$ decreased from 8.5 to 5.0 within a month followed by increase to 7.26 at 45 day, gradually declining to 4.76 in 3 months (Table 1). Serum globulin levels (g/dl) decreased from 5.36 to 2.46 within a month, followed by increase to 4.36 at 45 day, gradually declining to 2.1 in 3 months (Table 2). Serum concentrations of proteins and globulins decreased very significantly $(\mathrm{P}<0.01)$ from 0D to 90D. Serum proteins and globulins decreased significantly $(\mathrm{P}<0.05)$ from $0 \mathrm{D}$ to $30 \mathrm{D}$. Serum globulins decreased significantly $(\mathrm{P}<0.05)$ from 0D to 75D (Fig. 1).

Serum protein measurement constitutes a vital component of laboratory diagnostic evaluations in animals. Increased total protein concentration can result from increased level of albumin, globulin, or both. In the present study, the higher globulin concentrations led to higher total serum proteins. Elevation of gamma globulin concentration is common during chronic inflammatory diseases. Chronic or subacute bacterial infections can cause increases in globulin levels, particularly the gamma globulins resulting from production of antibodies in response to chronic antigenic stimulation.

The $\log 10$ titers of anti-Brucella antibodies by STAT (STAT titers) increased from 2.103 to 2.216 within a month and then gradually declined to 2.000 within 3 months (Table 3). MAT titers increased slightly from 2.605 to 2.705 within a month and then gradually declined to 2.404 within 3 months (Table 4). IHA titers increased slightly from 2.404 to 2.505 in 30 days and then started declining gradually after 45 days reaching 2.304 by 90 days (Table 5). Titers of anti-Brucella antibody by STAT, MAT and IHA did not differ significantly among themselves from 0D to 90D. ELISA titers declined from 1.412 to 1.406 by 45 days, increased to 1.493 
by 2 months and finally declined to 1.477 by 90 days (Table 6). Interestingly, in case of ELISA, there was a very significant ( $\mathrm{p}<0.01$ ) increase in titers from 0Day to 60D, 75D and 90D; from 30Day to 60D, 75D and 90D; and from 45Day to 60D, 75D and 90D, respectively (Fig. 2). Total leukocyte counts decreased from 8066.66 to 7733.33 within a month and then increased to 8466.66 by 60 day. The levels again declined to 7966.66 by 75 day and then rose to 10100 by 90 day (Table 7; Fig. 3). Percentage of lymphocytes decreased from 59.66 to 54.66 in one month, increased to 64 by 45 days and then gradually declined to 59 by day 90 (Table 8). Neutrophils increased from 36.66 to 41.66 by day 30, declined to 32.66 at 45 day, again rose to 44 by day 75 , finally reaching 37 by day 90 (Table 10). The levels of total leukocytes, lymphocytes and neutrophils did not differ significantly over a period of 90 days. However, monocytes decreased from 2 to 1.66 by day 30 , reached 1.33 by day 45 and maintained at this level till day 75 followed by an increase to 2.33 by day 90 (Table 9 ). Interestingly, the levels of monocytes increased significantly $(\mathrm{P}<0.05)$ from $45 \mathrm{D}$ to $60 \mathrm{D}$ and then decreased significantly $(\mathrm{P}<0.05)$ from 60D to 75D (Fig. 4). As evident from the results, overall suppression of humoral and cellular immune responses prevailed in the infected animals during the period of observation.

Gul et al. (2013) found no significant difference in total protein. However, El-Boshy et al. (2009) reported a significant $(\mathrm{p}<0.05)$ decrease in total protein in camel. El Azab (2015) evaluated protein fractions in Brucella-infected cows and reported that total protein and gamma globulin concentrations were increased in serologically positive cows and significantly higher than those of healthy cows. Increased total protein concentrations were due to the increase in gamma globulin concentrations only. Nath et al (2014) evaluated the blood biochemical metabolites of crossbred cattle suffering from brucellosis. Serum globulin of the affected cattle was significantly increased $(\mathrm{p}<0.05)$ in comparison to the healthy cattle. Hamada et al. (2013) and Abenga and Anosa (2005) observed an increased serum globulin level in Brucellosis affected cows.

Sikder et al (2012) carried out a hematological study to determine the variations in blood parameters of Brucellosis seropositive commercial dairy cattle. No significant $(\mathrm{p}<0.05)$ variations were found in TLC and DLC between the Brucellosis positive and negative group. However, slightly increased values of TLC and monocytes were recorded in the positive group. In addition, a little decline in the values of neutrophil was found in the same group. The values of lymphocytes remained unchanged. They concluded that Brucella organisms are not responsible for a significant change in the hematological values.

B. abortus is a gram negative intracellular bacterium; it induces the production of tumor necrosis factor alpha. Brucella is able to survive within host cells following phagocytosis by adapting to intracellular conditions and overcoming the host's normal immune defences (Kohler et al., 2003; Baldwin and Goenka, 2006). The organism can enter and replicate in a variety of cells including dendritic cells and macrophages (Gorvel, 2008). Brucellosis leads to serious changes in the blood as it affects some vital organs like liver. The assaying of biochemical parameters in cattle may be helpful in elucidating the pathogenesis of the adverse effects associated with brucellosis in cattle.

In our study, a generalized suppression of humoral and cellular immune responses prevailed in the infected animals during the period of observation of 3 months. This suggests that a therapeutic regime involving immunostimulants may help in recovery of the immune effector mechanisms of the animal and may alter the course of infection to the advantage of the host.

\section{References}

[1]. Abenga, J.N. and Anosa, V.O. (2005) Serum total protein \& creatine levels in experimental Gambian trypanosomosis of Vervet monkeys. Afr. J. Biotechnol., 4: 187-190.

[2]. Baldwin, C.L. and Goenka, R. (2006) Host immune responses to the intracellular bacterium Brucella: Does the bacterium instruct the host to facilitate chronic infection? Crit. Rev. Immunol., 26: 407-442.

[3]. El-Azab M F A (2015) Evaluation of serum enzyme activities and protein fractions in Brucella-infected cows. Turk J Vet Anim Sci 39: 480-484.

[4]. El-Boshy, M., Abbas, M., El-Khoderyl, H. and Osman, S. (2009) Cytokine response and clinicopathological findings in Brucella infected camels (Camelus dromedarius). Vet. Med., 54(1): 25-32.

[5]. Godfroid, J., Garin-Bastuji, B., Saegerman, C. and Blasco, J.M. (2013) Brucellosis in terrestrial wildlife. Sci. Tech. Rev. Off. Int. Epiz., 32(1): 27-42.

[6]. Gorvel, J.P., 2008. Brucella: a Mr "Hide"' converted into Dr Jekyll. Microbes Infect. 10, 1010-1013.

[7]. Gul, S.T., Khan, A., Ahmad, M. and Hussain, I. (2013) Seroprevalence of brucellosis and associated hemato-biochemical changes in Pakistani horses. Pak. J. Agric. Sci.,50(4): 745-750.

[8]. Hamada, D.M., Mohamed, A.H, Mabrouk, A., Emad, M. and Ah, M.E. (2013) Seroprevalence of abortion causing agents in Egyptian sheep and goat breeds and their effects on the animal's performance. J. Agric. Sci., 5(9): 92-101.

[9]. Jain, U., Bisht, B., Sahzad, P. and Dwivedi, K. (2013) Outbreak of brucellosis in buffaloes aborted in a village Mahuan, district Mainpuri, UP, India - A case report. Vet. World, 6(1): 51-52.

[10]. Kohler, S., Foulongne, V., Ouahrani-Bettache, S., Bourg, G., Teyssier, J., Ramuz, M.,

[11]. Kohler, S., Michaux-Charachon, S., Porte, F., Ramuz, M., Liautard, J.P., 2003. What is the nature of the replicative niche of a stealthy bug named Brucella? Trends Microbiol. 11, 215-219.

[12]. Kollannur, J.D., Rathore, R. and Chauhan, R.S. (2007) Epidemiology and economics of brucellosis in animals and its zoonotic significance. Proceedings of XIII International Congress in Animal Hygiene. International Society for Animal Hygiene. p466-468. 
[13]. Mohan A, Saxena HM, Malhotra P (2016) A comparison of titers of anti-Brucella antibodies of naturally infected and healthy vaccinated cattle by standard tube agglutination test, microtiter plate agglutination test, indirect hemagglutination assay, and indirect enzyme-linked immunosorbent assay. Vet. World 9(7): 717-722.

[14]. Moriyon, I., Grillo, M.J., Monreal, D., Gonzalez, D., Marin, C., Lopez-Goni, I., Mainar-Jaime, R.C., Moreno, E. and Blasco, J.M. (2004) Rough vaccines in animal brucellosis: Structural and genetic basis and present status. Vet. Res., 35(1): 1-38.

[15]. Nath R, Das S, Sarma S, Devi M (2014) Comparison of blood profiles between healthy and Brucella affected cattle, Veterinary World 7(9): 668-670.

[16]. Pandeya, Y.R., Joshi, D.D., Dhakal, S., Ghimire, L., Mahato, B.R., Chaulagain, S., Satyal, R.C. and Sah, S.K. (2013) Seroprevalence of brucellosis in different animal species of Kailali district Nepal. Int. J. Infect. Microbiol., 2(1): 22-25.

[17]. Schuurman, H.J. (1983) The serological response of adult cattle to vaccination with reduced dose Brucella abortus S19, a trial under Zambian conditions. Vet. Q., 5: 94-96.

[18]. Sikder S, Rahman SSM, Alim MA and Das S (2012) Haematological Variations in Brucella abortus Antibody Positive Cross-bred Cattle at Chittagong, Bangladesh. YYU Veteriner Fakultesi Dergisi 23 (3), 125 - 128.

List of figures:

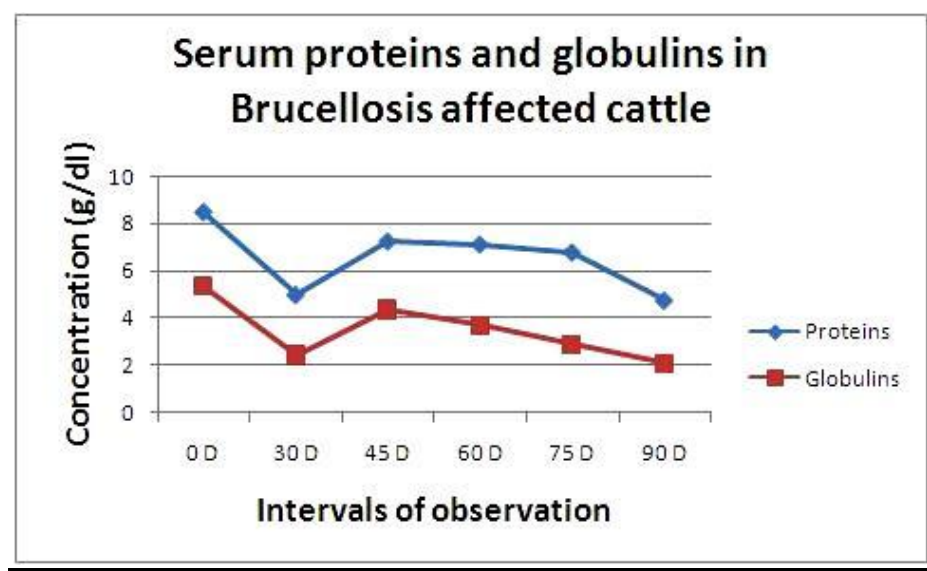

Fig. 1. Levels of total serum proteins and globulins in Brucellosis affected cattle

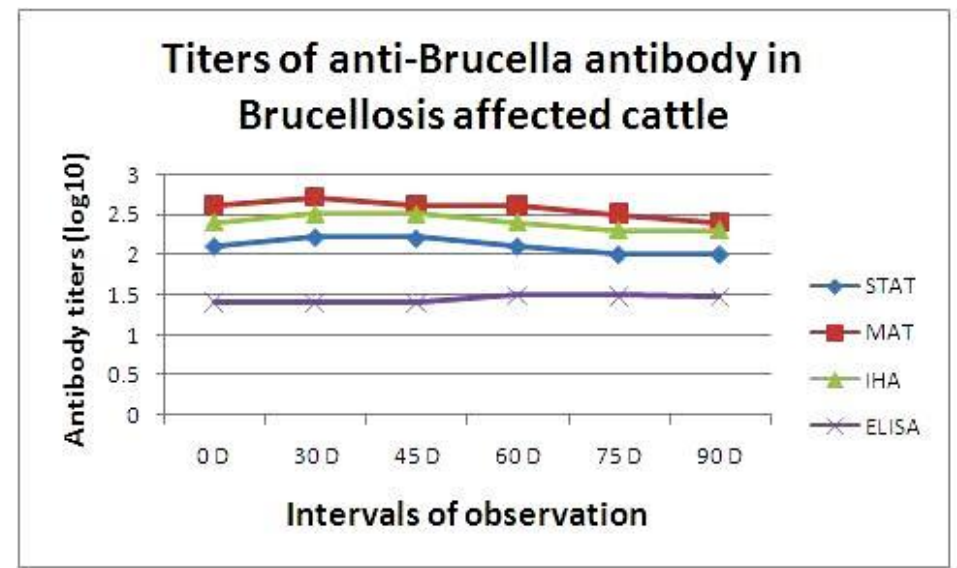

Fig. 2 Anti-Brucella antibodies in sera of Brucellosis affected cattle

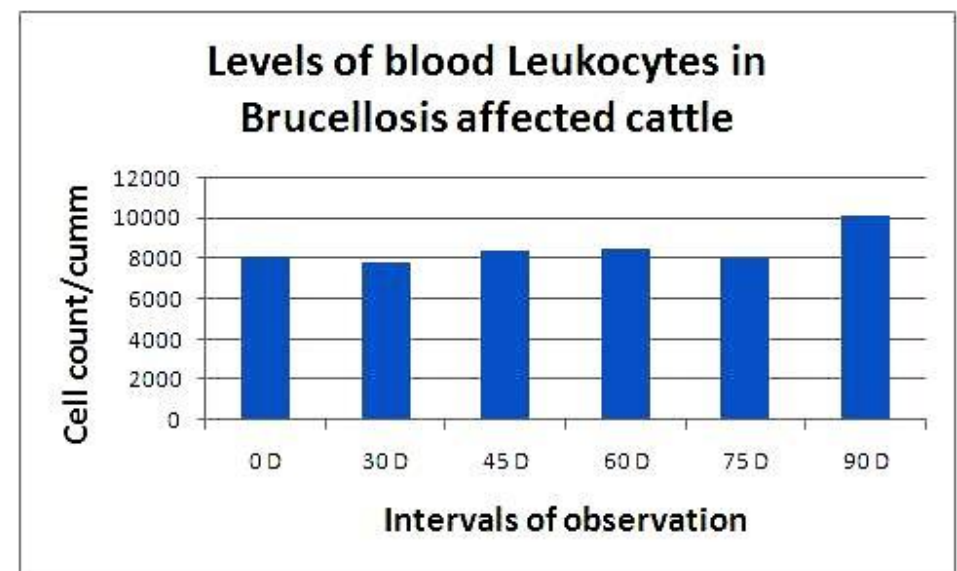

Fig. 3. Levels of total blood leukocytes in Brucellosis affected cattle 


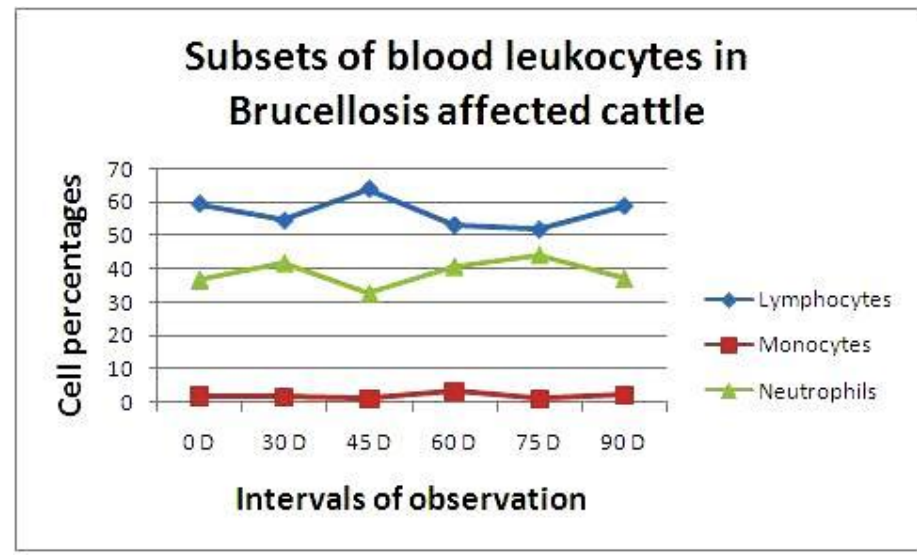

Fig. 4. Levels of leukocyte subsets in blood of Brucellosis affected cattle

Table 1: Total serum protein levels $(\mathrm{g} / \mathrm{dl})$ in Brucellosis affected cattle

\begin{tabular}{|l|l|l|l|l|l|l|}
\hline Sl. No. & $\mathbf{0}$ D & $\mathbf{3 0}$ D & 45 D & $\mathbf{6 0}$ D & $\mathbf{7 5 ~ D}$ & 90 D \\
\hline 1 & 8.0 & 5.4 & 7.0 & 6.9 & 6.3 & 5.2 \\
\hline 2 & 9.3 & 2.9 & 7.2 & 6.9 & 6.7 & 2.5 \\
\hline 3 & 8.2 & 6.7 & 7.6 & 7.6 & 7.4 & 6.6 \\
\hline Mean & $\mathbf{8 . 5}$ & $\mathbf{5 . 0}$ & $\mathbf{7 . 2 6}$ & $\mathbf{7 . 1 3}$ & $\mathbf{6 . 8}$ & $\mathbf{4 . 7 6}$ \\
$\mathbf{\text { SD }}$ & $\mathbf{\mathbf { 0 . 7 }}$ & $\mathbf{+ 1 . 9 3}$ & $\mathbf{+ 0 . 3 0}$ & $\mathbf{+ 0 . 4 0}$ & $\underline{\mathbf{+ 0 . 5 5}}$ & $\underline{\mathbf{+ 2 . 0 8}}$ \\
\hline
\end{tabular}

Table 2: Total serum globulin levels $(\mathrm{g} / \mathrm{dl})$ in Brucellosis affected cattle

\begin{tabular}{|l|l|l|l|l|l|l|}
\hline Sl.No. & 0 D & 30 D & 45 D & 60 D & 75 D & 90 D \\
\hline 1 & 5.5 & 2.2 & 4.1 & 2.6 & 2.3 & 2.1 \\
\hline 2 & 5.7 & 1.6 & 4.2 & 3.8 & 1.8 & 1.4 \\
\hline 3 & 4.9 & 3.6 & 4.8 & 4.7 & 4.6 & 2.8 \\
\hline Mean & $\mathbf{5 . 3 6}$ & $\mathbf{2 . 4 6}$ & $\mathbf{4 . 3 6}$ & $\mathbf{3 . 7}$ & $\mathbf{2 . 9}$ & $\mathbf{2 . 1}$ \\
$\underline{\mathbf{S D}}$ & $\underline{\mathbf{+ 0 . 4 1}}$ & $\underline{\mathbf{+ 1 . 0 2}}$ & $\underline{\mathbf{+ 0 . 3 7}}$ & $\underline{\mathbf{+ 1 . 0 5}}$ & $\underline{\mathbf{1 1 . 4 9}}$ & $\underline{\mathbf{+ 0 . 7}}$ \\
\hline
\end{tabular}

Table 3: Anti-Brucella antibody titres by STAT in Brucellosis affected cattle

\begin{tabular}{|l|l|l|l|l|l|l|}
\hline \multirow{2}{*}{$\begin{array}{l}\text { Sl. } \\
\text { No. }\end{array}$} & Antibody titres by STAT \\
\cline { 2 - 7 } & $\mathbf{0}$ D & $\mathbf{3 0} \mathbf{D}$ & $\mathbf{4 5} \mathbf{D}$ & $\mathbf{6 0} \mathbf{D}$ & $\mathbf{7 5} \mathbf{D}$ & $\mathbf{9 0} \mathbf{D}$ \\
\hline 1 & 2.806 & 2.806 & 2.806 & 2.806 & 2.806 & 2.806 \\
\hline 2 & 1.903 & 2.204 & 1.903 & 1.903 & 1.602 & 1.602 \\
\hline 3 & 1.602 & 1.602 & 1.903 & 1.602 & 1.602 & 1.602 \\
\hline Mean & $\mathbf{2 . 1 0 3}$ & $\mathbf{2 . 2 1 6}$ & $\mathbf{2 . 2 0 4}$ & $\mathbf{2 . 1 0 3}$ & $\mathbf{2 . 0 0 0}$ & $\mathbf{2 . 0 0 0}$ \\
$\mathbf{\text { SD }}$ & $\mathbf{\mathbf { 0 . 6 2 }}$ & $\mathbf{\mathbf { 0 . 6 0 }}$ & $\mathbf{\mathbf { 0 . 5 2 }}$ & $\mathbf{\mathbf { 0 . 6 2 }}$ & $\mathbf{\mathbf { 0 . 6 9 }}$ & $\mathbf{\mathbf { 0 . 6 9 }}$ \\
\hline
\end{tabular}

Table 4: Anti-Brucella antibody titres by MAT in Brucellosis affected cattle

\begin{tabular}{|l|l|l|l|l|l|l|}
\hline \multirow{2}{*}{$\begin{array}{l}\text { Sl. } \\
\text { No. }\end{array}$} & \multicolumn{2}{|c|}{ Antibody titres by MAT } \\
\cline { 2 - 7 } & $\mathbf{0}$ D & 30 D & 45 D & 60 D & 75 D & 90 D \\
\hline 1 & 3.709 & 3.408 & 3.107 & 3.107 & 3.107 & 2.806 \\
\hline 2 & 2.204 & 2.806 & 2.806 & 2.806 & 2.505 & 2.505 \\
\hline 3 & 1.903 & 1.903 & 1.903 & 1.903 & 1.903 & 1.903 \\
\hline Mean & $\mathbf{2 . 6 0 5}$ & $\mathbf{2 . 7 0 5}$ & $\mathbf{2 . 6 0 5}$ & $\mathbf{2 . 6 0 5}$ & $\mathbf{2 . 5 0 5}$ & $\mathbf{2 . 4 0 4}$ \\
$\mathbf{\text { SD }}$ & $\mathbf{\mathbf { 0 . 9 6 }}$ & $\mathbf{\mathbf { 0 . 7 5 }}$ & $\mathbf{\mathbf { 0 . 6 2 }}$ & $\mathbf{\mathbf { 0 . 6 2 }}$ & $\mathbf{\mathbf { 0 . 6 0 }}$ & $\mathbf{\mathbf { 0 . 4 5 }}$ \\
\hline
\end{tabular}

Table 5: Anti-Brucella antibody titres by IHA in Brucellosis affected cattle

\begin{tabular}{|l|l|l|l|l|l|l|}
\hline \multirow{2}{*}{$\begin{array}{l}\text { Sl. } \\
\text { No. }\end{array}$} & \multicolumn{6}{|l|}{ Antibody titres by IHA } \\
\cline { 2 - 7 } & $\mathbf{0}$ D & 30 D & 45 D & 60 D & 75 D & 90 D \\
\hline 1 & 3.107 & 3.107 & 2.806 & 2.505 & 2.505 & 2.505 \\
\hline 2 & 2.505 & 2.806 & 2.806 & 2.806 & 2.505 & 2.505 \\
\hline 3 & 1.602 & 1.602 & 1.903 & 1.903 & 1.903 & 1.903 \\
\hline Mean & $\mathbf{2 . 4 0 4}$ & $\mathbf{2 . 5 0 5}$ & $\mathbf{2 . 5 0 5}$ & $\mathbf{2 . 4 0 4}$ & $\mathbf{2 . 3 0 4}$ & $\mathbf{2 . 3 0 4}$ \\
$\mathbf{\text { SD }}$ & $\mathbf{\mathbf { 0 . 7 5 }}$ & $\underline{\mathbf{+ 0 . 7 9}}$ & $\underline{\mathbf{0 . 5 2}}$ & $\mathbf{\mathbf { 0 . 4 5 }}$ & $\mathbf{\mathbf { 0 . 3 4 }}$ & $\mathbf{\mathbf { 0 . 3 4 }}$ \\
\hline
\end{tabular}

Table 6: Anti-Brucella antibody titres by i-ELISA in Brucellosis affected cattle

\begin{tabular}{|c|c|c|c|c|c|c|}
\hline \multirow{2}{*}{$\begin{array}{l}\text { Sl. } \\
\text { No. }\end{array}$} & \multicolumn{6}{|c|}{ Antibody titres by ELISA } \\
\hline & OD & $30 \mathrm{D}$ & $45 \mathrm{D}$ & $60 \mathrm{D}$ & $75 \mathrm{D}$ & $90 \mathrm{D}$ \\
\hline 1 & 1.4243 & 1.4137 & 1.4091 & 1.4890 & 1.4631 & 1.4528 \\
\hline 2 & 1.4251 & 1.4145 & 1.4128 & 1.4911 & 1.4985 & 1.4846 \\
\hline 3 & 1.3878 & 1.3855 & 1.3977 & 1.4992 & 1.5016 & 1.4953 \\
\hline $\begin{array}{l}\text { Mean } \\
+ \text { SD }\end{array}$ & $\begin{array}{r}1.412 \\
\pm 0.02\end{array}$ & $\begin{array}{l}1.404 \\
\pm 0.01\end{array}$ & $\begin{array}{l}1.406 \\
\pm 0.007\end{array}$ & $\begin{array}{l}1.493 \\
\pm 0.005\end{array}$ & $\begin{array}{l}1.487 \\
+0.021\end{array}$ & $\begin{array}{l}1.477 \\
+0.022\end{array}$ \\
\hline
\end{tabular}


Table 7: Total blood leukocyte count (TLC) in Brucellosis affected cattle

\begin{tabular}{|c|c|c|c|c|c|c|}
\hline Sl.No. & O D & 30D & $45 \mathrm{D}$ & $60 \mathrm{D}$ & $75 \mathrm{D}$ & 90 D \\
\hline 1 & 7400 & 7200 & 8500 & 7800 & 9700 & 11200 \\
\hline 2 & 7100 & 5700 & 8400 & 9200 & 6400 & 8300 \\
\hline 3 & 9700 & 10300 & 8300 & 8400 & 7800 & 10800 \\
\hline $\begin{array}{l}\text { Mean } \\
\pm \text { SD }\end{array}$ & $\begin{array}{l}8066.66 \\
+1422.43\end{array}$ & $\begin{array}{l}\mathbf{7 7 3 3 . 3 3} \\
+2345.91 \\
\end{array}$ & $\begin{array}{l}8400 \\
+100 \\
\end{array}$ & $\begin{array}{l}8466.66 \\
+702.37 \\
\end{array}$ & $\begin{array}{l}7966.66 \\
\pm 1656.30 \\
\end{array}$ & $\begin{array}{l}10100 \\
+1571.62\end{array}$ \\
\hline
\end{tabular}

Table 8: Blood lymphocyte counts in Brucellosis affected cattle

\begin{tabular}{|c|c|c|c|c|c|c|}
\hline Sl.No. & O D & 30D & 45 D & $60 \mathrm{D}$ & $75 \mathrm{D}$ & $90 \mathrm{D}$ \\
\hline 1 & 54 & 50 & 67 & 50 & 54 & 54 \\
\hline 2 & 50 & 56 & 57 & 50 & 50 & 63 \\
\hline 3 & 75 & 58 & 68 & 60 & 52 & 60 \\
\hline $\begin{array}{l}\text { Mean } \\
\pm \text { SD }\end{array}$ & $\begin{array}{l}59.66 \\
+13.42 \\
\end{array}$ & $\begin{array}{l}54.66 \\
+4.16\end{array}$ & $\begin{array}{l}64 \\
\pm 6.08\end{array}$ & $\begin{array}{l}\mathbf{5 3 . 3 3} \\
+\mathbf{5 . 7 7} \\
\end{array}$ & $\begin{array}{r}52 \\
\pm 2 \\
\end{array}$ & $\begin{array}{l}59 \\
\pm 4.58 \\
\end{array}$ \\
\hline
\end{tabular}

Table 9: Blood monocyte counts in Brucellosis affected cattle

\begin{tabular}{|c|c|c|c|c|c|c|}
\hline Sl.No. & O D & 30D & 45 D & $60 \mathrm{D}$ & $75 \mathrm{D}$ & 90 D \\
\hline 1 & 2 & 2 & 1 & 3 & 2 & 3 \\
\hline 2 & 2 & 1 & 1 & 3 & 1 & 3 \\
\hline 3 & 2 & 2 & 2 & 4 & 1 & 1 \\
\hline $\begin{array}{l}\text { Mean } \\
\pm \text { SD }\end{array}$ & $\begin{array}{l}2 \\
\pm 0 \\
\end{array}$ & $\begin{array}{r}1.666 \\
+0.57 \\
\end{array}$ & $\begin{array}{l}1.333 \\
\pm 0.57 \\
\end{array}$ & $\begin{array}{l}\mathbf{3 . 3 3 3} \\
\pm \mathbf{0 . 5 7} \\
\end{array}$ & $\begin{array}{l}1.333 \\
\pm 0.57 \\
\end{array}$ & $\begin{array}{r}2.333 \\
\pm 1.15 \\
\end{array}$ \\
\hline
\end{tabular}

Table 10: Blood neutrophil counts in Brucellosis affected cattle

\begin{tabular}{|c|c|c|c|c|c|c|}
\hline Sl.No. & O D & 30D & $45 \mathrm{D}$ & $60 \mathrm{D}$ & $75 \mathrm{D}$ & $90 \mathrm{D}$ \\
\hline 1 & 42 & 46 & 30 & 45 & 40 & 41 \\
\hline 2 & 46 & 41 & 40 & 42 & 47 & 32 \\
\hline 3 & 22 & 38 & 28 & 35 & 45 & 38 \\
\hline $\begin{array}{l}\text { Mean } \\
\pm \text { SD }\end{array}$ & $\begin{array}{l}36.666 \\
+12.85 \\
\end{array}$ & $\begin{array}{l}41.666 \\
+4.04 \\
\end{array}$ & $\begin{array}{l}32.666 \\
+5.24 \\
\end{array}$ & $\begin{array}{r}40.666 \\
+5.131 \\
\end{array}$ & $\begin{array}{l}44 \\
+3.60 \\
\end{array}$ & $\begin{array}{l}37 \\
+4.58 \\
\end{array}$ \\
\hline
\end{tabular}

